\title{
THE NATURE OF TUMOR ANTIGEN OF ADENOVIRUS TYPE 12 AND ITS FORMATION IN CULTURED CELLS AFTER INFECTION
}

\author{
HiRoto SHIMOJO, HiROSHI YAMAMO'TO, EIKo YOSHIKAWA AND \\ TADASHI YAMASHITA \\ Department of Enteroviruses, National Institute of Health, Tokyo
}

(Received : December 13th, 1965)

\begin{abstract}
Tumor antigen in hamster tumors induced by adenovirus type 12 could be assorted by the complement-fixation test into two antigens: TS antigen, nonprecipitable by ultracentrifugation, and TP antigen, precipitable by ultracentrifugation. Tumor antigen was formed prior to the formation of infectious mature virus, viral coat protein, viral DNA or viral antigens in the lytic infection of human embryonic kidney cell cultures with adenovirus type 12. In the non-lytic infection of cultured hamster cells with adenovirus type 12, tumor antigen was formed as early as in human embryonic kidney cell cultures, but no infectious virus was formed. On the basis of these findings, the significance of tumor antigen in virus infection and the relationship between the virus infection and the transformation of hamster cells are discussed.
\end{abstract}

\section{INTRODUCTION}

Adenovirus type 12 (abbreviated as Ad 12) produced tumors in hamsters when injected into suckling hamsters (Trentin, Yabe and Taylor, 1962). Immediately after the discovery, Huebner, Rowe and Lane (1962) found that sera from some tumor bearing hamsters (abbreviated as $\mathrm{TBH}$ ) contained antibody, which was detected by the complment-fixation test (abbreviated as CFT) with viral antigen. Further investigation (Huebner et al., 1963) showed that there was a specific antigen (or specific antigens) in hamster tumors induced by Ad 12 and that the sera from TBH contained antibody against the specific antigen. The antigen was distinct from adenovirus group specific viral antigen (A anitgen) but had some relationship with adenovirus type specific viral antigen (C antigen) (Huebner et al., 1964). The same antigen was found in hamster tumors induced by adenovirus type 18 and was named "tumor antigen" (abbreviated as $\mathrm{T}$ antigen) (Huebner et al., 1963). $\mathrm{T}$ antigen was also found in cells transformed in vitro by Ad 12 (McBride and Wiener, 1964). The existence of $\mathrm{T}$ antigen was confirmed by fluorescent antibody technique (Pope and Rowe, 1964).

Similar antigens were found in hamster tumors induced by adenovirus type 7 (Larson et al., 1965), adenovirus type 3 (Huebner et al., 1965), SV40 (Black et al., 1963), polyoma virus (Habel, 1965) and Schmidt-Ruppin strain of Rous sarcoma virus (Huebner et al., 1964) but these antigens were distinct serologically from $T$ antigen of Ad 12.

This study was undertaken to follow up the formation of $\mathrm{T}$ antigen in cultured

下条寛人・山本弘史・吉川映子・山下正（国立予防衛生研究所腸内ウイルス部） 
cells after infection with Ad 12. The results showed that $\mathrm{T}$ antigen was formed earlier than infectious virus after the infection and revealed some of the natures of the antigen. The following is a description of the results and a discussion of the nature of $\mathrm{T}$ antigen and of the relationship between infection of $\mathrm{Ad} 12$ and transformation of hamster cells.

\section{Materials AND Methods}

Virus: Ad 12 Huie strain was used in this study. Virus stocks were prepared either in HeLa cell cultures or in human embryonic kidney cell cultures (abbreviated as HEK) infected with the virus. The virus was titrated in HEK tubes and virus titer was shown in TCID $_{50}$ (Shimojo et al., 1966).

Complement-fixation test: The method of CFT was the same as that which had been used for the identification of viruses in our Institute (Okuno, Oya and Ito, 1961) as a modification of Fulton-Dumbell's drop technique (1949) on disposal CFT trays. One drop of serum, one drop of antigen and then two drops of guinea pig complement containing 1.7 to 2.2 units were delivered successively in a depsession on a disposal CFT tray and the mixture was allowed to stand overnight at $4 \mathrm{C}$. Two drops of hemolytic system, composed of approximately 20 units of hemolysin and a $2.5 \%$ sheep red blood cell suspension, were then added. The degree of hemolysis was read after the mixture was incubated at $36 \mathrm{C}$ for $30 \mathrm{~min}$, then at $4 \mathrm{C}$ for $60 \mathrm{~min}$. Veronal buffered saline (abbreviated as VBS) (Fulton \& Dumbell, 1949), was used as diluent. The highest dilution of antiserum, which showed hemolysis of less than $25 \%$, was taken as CF antibody titer. The highest dilution of antigen, which showed hemolysis of less than $25 \%$ against 4 units of antiserum, was taken as CF antigen titer.

Antiserum: As antiserum against $\mathrm{T}$ antigen (abbreviated as Anti-T), sera from TBH were used. Bady hamsters, not more than 48 hr old, were injected subcutaneously with Ad 12 and large tumors were formed after 6 to 8 weeks. The animals were then bled and the sera were used as TBH sera. Antibody titers of TBH sera were determined by CFT with the standard $\mathrm{T}$ antigen. A $20 \%$ emulsion of tumor tissue from TBH was prepared in VBS and was centrifuged at 3,000 rpm for $20 \mathrm{~min}$. The supernatant was kept in a freezer and was used as the standard $\mathrm{T}$ antigen. An example of CFT with TBH serum is shown in Table 1. The antigen content in a test material was determined by CFT with 4 units (occasionally 2 units) of anti-T serum.

As antiserum against adenovirus type specific antigen (abbreviated as anti-C), two kinds of antisera, immunized rabbit and guinea pig sera, were used. Rabbits were hyperimmunized with Ad 12 which was harvested from monkey kidney cell cultures and purified by the fluorocarbon treatment. The rabbit antisera showed rather high $\mathrm{CF}$ titers against Ad 12 but they were slightly anticomplementary up to the dilution of $1: 16$. They also showed antibody against monkey kidney cells but no antibody against HEK or hamster cells. An example of CFT of a rabbit antiserum is shown in Table 2.

Guinea pigs were immunized with one intracerebral injection of Ad 12, followed by an intraperitoneal booster injection after 4 weeks. Ad 12, with a high virus titer, harvested from HEK and purified by the fluorocarbon treatment, was used for the immunization (immunization method, recommended by Ashihara, 1965). The CF antibody titers against Ad 12 in guinea pig sera were not so high but the sera were specific, showing no antibody against HEK. None of the rabbit antisera and guinea 
Table 1. CFT of tumor bearing hamster serum (TBH-2)

\begin{tabular}{|c|c|c|c|c|c|c|c|c|}
\hline \multirow{2}{*}{ Antigen } & & \multicolumn{7}{|c|}{ Serum dilution } \\
\hline & & $1: 4$ & $1: 8$ & $1: 16$ & $1: 32$ & $1: 64$ & $1: 128$ & $\mathrm{AC}^{* *}$ \\
\hline Ad 5(\$2) & $1: 16$ & $0 *$ & 0 & 0 & 0 & 0 & 0 & 0 \\
\hline \multirow{3}{*}{$\mathrm{T}$ Antigen } & $1: 1$ & & & 4 & 4 & 3 & $0^{\prime}$ & 0 \\
\hline & $1: 2$ & & & 3 & 3 & 1 & $0^{\prime}$ & 0 \\
\hline & $1: 4$ & & & 1 & 0 & 0 & 0 & 0 \\
\hline \multirow{3}{*}{$\begin{array}{l}\text { T Antigen } \\
\text { SUC }^{* * *}\end{array}$} & $1: 1$ & & & 4 & 4 & 3 & $0^{\prime}$ & 0 \\
\hline & $1: 2$ & & & 4 & 3 & $0^{\prime}$ & $0^{\prime}$ & 0 \\
\hline & $1: 4$ & & & $0^{\prime}$ & $0^{\prime}$ & 0 & 0 & 0 \\
\hline $\mathrm{SC}^{* *}$ & & 0 & 0 & 0 & 0 & 0 & 0 & \\
\hline
\end{tabular}

* Figures indicate the degree of hemolysis. 0 : Complete hemolysis, $0^{\prime}:$ Intermediate between 0 and $1,1: 75 \%$ hemolysis, $2: 50 \%$ hemolysis, $3: 25 \%$ hemolysis, $4:$ no hemolysis.

** AC : Antigen control, SC : Serum control.

*** Supernatant of $\mathrm{T}$ antigen after ultracentrifugation at $30,000 \mathrm{rpm}$ for $60 \mathrm{~min}$.

Table 2. CFT of anti-Ad 12 rabbit immune serum (R-1)

\begin{tabular}{|c|c|c|c|c|c|c|c|}
\hline \multirow{2}{*}{ Antigen } & & \multicolumn{6}{|c|}{ Serum dilution } \\
\hline & & $1: 32$ & $1: 64$ & $1: 128$ & $1: 256$ & $1: 512$ & $\mathrm{AC}$ \\
\hline \multirow{4}{*}{ Ad $12(\$ 11)$} & $1: 4$ & 4 & 4 & 4 & 3 & 2 & 0 \\
\hline & $1: 8$ & 4 & 4 & 3 & 3 & $0^{\prime}$ & 0 \\
\hline & $1: 16$ & 4 & 3 & 2 & $0^{\prime}$ & 0 & 0 \\
\hline & $1: 32$ & 2 & $0^{\prime}$ & $0^{\prime}$ & 0 & 0 & 0 \\
\hline \multirow{4}{*}{ Ad 5( } & $1: 8$ & 0 & 0 & 0 & 0 & 0 & 0 \\
\hline & $1: 16$ & 0 & 0 & 0 & 0 & 0 & 0 \\
\hline & $1: 32$ & 0 & 0 & 0 & 0 & 0 & 0 \\
\hline & $1: 64$ & 0 & 0 & 0 & 0 & 0 & 0 \\
\hline \multirow{4}{*}{ T Antigen } & $1: 4$ & 4 & 4 & 3 & 2 & 2 & 2 \\
\hline & $1: 8$ & 3 & 2 & 1 & $0^{\prime}$ & 0 & 0 \\
\hline & $1: 16$ & 2 & 2 & 0 & 0 & 0 & 0 \\
\hline & $1: 32$ & 2 & 1 & 0 & 0 & 0 & 0 \\
\hline $\begin{array}{l}T \text { Antigen } \\
\text { SUC }\end{array}$ & $1: 4$ & 0 & 0 & 0 & 0 & 0 & 0 \\
\hline $\mathrm{SC}$ & & 0 & 0 & 0 & 0 & 0 & \\
\hline
\end{tabular}

pig antisera showed antibody agaist any type of adenovirus other than Ad 12 at the dilution of $1: 32$, and they could be used as specific anti-C antisera.

As antiserum against adenovirus group specific antigen (abbreviated as Anti-A), hamster sera immunized with adenovirus type 5 were used. The sera showed CF 
antibodies both against adenovirus type 5 and against Ad 12 (Table 3). Antibody against Ad 12 was regarded as anti-A antibody and four units of anti-A were used to determine the content of $\mathrm{A}$ antigen in the test material.

Cultured cells: As a lytic system, HEK was used. The preparation of HEK is described elsewhere (Shimojo et al., 1966). As a non-lytic system, cultured hamster cells were used. In preliminary examinations, hamster embryos or kidneys from suckling hamsters were minced and treated with $0.2 \%$ trypsin (Difco $1: 250$ ). The cell suspensions thus prepared were cultured in bottles and used for the studies. In later examinations, various tissues such as brain, muscle (diaphragm or muscle tissues from legs), kidney tissue, etc., were taken out of suckling hamsters and minced with

Table 3. CFT of anti-Ad 5 hamster serum (H-5)

\begin{tabular}{|c|c|c|c|c|c|c|c|c|}
\hline \multirow{2}{*}{ Antigen } & & \multicolumn{7}{|c|}{ Serum dilution } \\
\hline & & $1: 16$ & $1: 32$ & $1: 64$ & $1: 128$ & $1: 256$ & $1: 512$ & $\mathrm{AC}$ \\
\hline \multirow{5}{*}{ Ad $5(\$ 2)$} & $1: 16$ & 4 & 4 & 4 & 4 & 4 & 0 & 0 \\
\hline & $1: 32$ & 4 & 4 & 4 & 4 & 4 & 1 & 0 \\
\hline & $1: 64$ & 4 & 4 & 4 & 4 & 4 & 3 & 0 \\
\hline & $1: 128$ & 4 & 4 & 4 & 4 & 4 & 3 & 0 \\
\hline & $1: 256$ & 4 & 4 & 4 & 4 & 4 & $0^{\prime}$ & 0 \\
\hline \multirow{5}{*}{ Ad $12(\$ 11)$} & $1: 4$ & 4 & 4 & 4 & 4 & 3 & 1 & $0^{\prime}$ \\
\hline & $1: 8$ & 4 & 4 & 4 & 4 & 3 & 0 & 0 \\
\hline & $1: 16$ & 4 & 4 & 4 & 4 & 3 & 0 & 0 \\
\hline & $1: 32$ & 4 & 4 & 4 & 4 & 3 & 0 & 0 \\
\hline & $1: 64$ & 2 & 1 & 1 & 1 & 0 & 0 & 0 \\
\hline $\mathrm{SC}$ & & 0 & 0 & 0 & 0 & 0 & 0 & \\
\hline
\end{tabular}

scissors. The minced materials were directly placed into culture bottles with growth medium. Eagle's MEM (Eagle, 1959) supplemented with $10 \%$ bovine serum was used as the growth medium. After an incubation at $36 \mathrm{C}$ for five days an outgrowth from masses of minced tissue was observed under a microscope and the medium was changed to fresh growth medium. By this procedure masses of minced tissue were washed off, leaving the outgrowing cells on the surface of the glass. One more change of the growth medium was enough to make a confluent monolayer without remains of minced tissue masses. The monolayer cells were then harvested with EDTA-trypsin $(0.01 \%$ EDTA, 0.1\% trypsin (Difco 1:250), in phosphate buffered saline), resuspended in fresh growth medium at the concentration of $10^{5}$ cells $/ \mathrm{ml}$, dispensed in appropriate tissue culture bottles and incubated at $36 \mathrm{C}$. After an incubation of 5 to 7 days, a confluent monolayer was formed.

Examination of the formation of antigens and virus in cultured cells: After the formation of complete monolayer of cultured cells, the growth medium was discarded. The cells were then washed once with phosphate buffered saline (abbreviated 
as PBS) and maintenance medium (Eagle's MEM without serum, sodium bicarbonate $0.15 \%$ ) was added. The virus was then seeded according to the design of the experiment. Prior to the above procedure, part of cell cultures was used for the enumeration of cells in the bottle and the dose of virus seeded was adjusted to obtain the designed input multiplicity of infection.

Virus-inoculated bottles were kept at $36 \mathrm{C}$ for $4 \mathrm{hr}$; then the medium was changed to fresh maintenance medium and the bottles were further incubated at $36 \mathrm{C}$. Bottles were taken out of the incubator at the planned time after the infection and cells were harvested in PBS by EDTA-trypsin treatment. In preliminary examinations, cell suspensions with various concentrations were used. In later examinations, cell suspensions at the concentration of $2 \times 10^{6} \mathrm{cells} / \mathrm{ml}$ were used throughout. The cells in suspensions were then disintegrated by sonication $(10 \mathrm{KC})$ for $5 \mathrm{~min}$ and centrifuged at 3,000 rpm for $20 \mathrm{~min}$. The supernatant was used as the test material. Its infectivity was titrated in HEK tubes and its antigen contents were measured by CFT.

\section{RESULTS}

\section{Results of Preliminary Examinations}

Preliminary exminations of the formation of antigens and virus were carried out in cultured hamster embryonic cells, hamster kidney cells and HEK (Tables 4, 5 and 6). The results can be summarized as follows:

Table. 4. Development of adenovirus 12 and its antigens in cultured hamster embryonic cells $\dagger$

\begin{tabular}{ccccc}
\hline \multirow{2}{*}{$\begin{array}{c}\text { Time after } \\
\text { inoculation }\end{array}$} & Infectivity & \multicolumn{3}{c}{ Antigen titre with } \\
\cline { 3 - 5 } & & $\begin{array}{c}\text { Anti. } \\
\text { TBH-2 }\end{array}$ & $\begin{array}{c}\text { Anti-C } \\
\text { R-1 }\end{array}$ & $\begin{array}{c}\text { Anti-A } \\
\text { H-5 }\end{array}$ \\
\hline 24 hrs & $2.5^{*}$ & $0^{* * *}$ & 0 & 0 \\
$48 "$ & 1.5 & $1: 1$ & 0 & 0 \\
3 days & 1.5 & $1: 1$ & 0 & 0 \\
$4 "$ & 1.5 & $1: 1$ & 0 & 0 \\
$5 "$ & 1.7 & $1: 1^{* *}$ & $0^{* *}$ & $0^{* *}$ \\
$6 "$ & ND & $0^{* * *}$ & $0^{* *}$ & $0^{* *}$ \\
$7 "$ & 1.5 & $1: 1^{* *}$ & $0^{* *}$ & $0^{* *}$ \\
$14 "$ & ND & $1: 1$ & 0 & 0
\end{tabular}

$\dagger$ Cells were infected with an input multiplicity $2.0 \mathrm{TCID}_{50}$ per cell and the test materials were prepared from cell suspension with the concentration of $5 \times 10^{6}$ cells $/ \mathrm{ml}$.

* Log TCID to $_{0}$ per $0.2 \mathrm{ml}$.

** Results after removal of anti-complementary activity by fluorocarbon treatment.

*** 0 means negative CFT with the undiluted antigen and $\mathrm{O}^{\prime}$ traces of CFT with the undiluted antigen.

a) In cultured hamster embryonic cells, neither virus multiplication nor cytopathic effect (abdreviated as CPE) was observed after infection with Ad 12. T antigen was formed as early as $24 \mathrm{hr}$ after infection but neither A nor C antigen could be detected. 
Table 5. Development of adenovirus 12 antigens in cultured hamster kidney cells*

\begin{tabular}{cccc}
\hline & \multicolumn{3}{c}{ Antigen titer with } \\
\cline { 2 - 4 } Time after inoculation & Anti-T & Anti-C & Anti-A \\
TBH-5 -2 & R-1 & 0 \\
\hline 12 hrs & 0 & 0 & 0 \\
$24 \prime \prime$ & $1: 1$ & $1: 1$ & 0 \\
$48 \prime \prime$ & $1: 2$ & 0 & 0 \\
$72 \prime \prime$ & $1: 2$ & $0^{\prime}$ & 0 \\
\hline
\end{tabular}

* Cells were infected with an input multiplicity $2.0 \mathrm{TCID}_{50}$ per cell and the test materials were prepared from cell suspension with the concentration of $4 \times 10^{6} \mathrm{cells} / \mathrm{ml}$.

Table 6. Development of adenovirus 12 and its antigens in HEK*

\begin{tabular}{|c|c|c|c|c|c|c|}
\hline \multirow{2}{*}{$\begin{array}{l}\text { Time after } \\
\text { inoculation }\end{array}$} & \multirow[b]{2}{*}{ CEP } & \multirow[b]{2}{*}{ Infectivity } & \multicolumn{4}{|c|}{ Antigen titer with } \\
\hline & & & & $\begin{array}{l}\text { Anti T } \\
\mathrm{TBH}-2\end{array}$ & $\begin{array}{c}\text { Anti-C } \\
\text { R-1 }\end{array}$ & $\begin{array}{c}\text { Anti A } \\
\mathrm{H}-5\end{array}$ \\
\hline $12 \mathrm{hrs}$ & - & 2.0 & & 0 & 0 & 0 \\
\hline $24 \prime \prime$ & - & 3.3 & $1: 4$ & $1: 2^{* *}$ & 0 & 0 \\
\hline 48 & \pm & 7.0 & & $1: 8$ & $1: 32$ & $1: 32$ \\
\hline 3 days & + & 7.5 & & $1: 16$ & $1: 64$ & $1: 32$ \\
\hline $4 \prime \prime$ & + & 7.3 & & $1: 16$ & $1: 64$ & $1: 64$ \\
\hline $5 \prime \prime$ & ++ & 7.7 & & $1: 16$ & $1: 64$ & $1: 128$ \\
\hline $6 \prime \prime$ & ++ & 7.5 & $1: 16$ & $1: 8$ & $1: 64$ & $1: 128$ \\
\hline $8 \prime \prime$ & +++ & 6.7 & & $1: 2$ & $1: 64$ & $1: 64$ \\
\hline
\end{tabular}

* Cells were infected with an input multiplicity of $1.6 \mathrm{TCID}_{50}$ per cell and the test materials were prepared from cell suspensions with the concentration of $2.4 \times 10^{6}$ cells $/ \mathrm{ml}$.

** Two antigen titers were obtained in duplicate tests. An antigen titer shows that the same antigen titres were obtained in duplicate tests.

b) In cultured hamster kidney cells, the result was the same as that in cultured hamster embryonic cells, save for a small quantity of $\mathrm{C}$ antigen was detected only 24 hrs after infection.

c) In HEK, CPE and virus multiplication were noted $48 \mathrm{hr}$ after infection. CPE progressed gradually and cells degenerated completely in several days. $\mathrm{C}$ antigen and $\mathrm{A}$ antigen were formed along with the multiplication of virus after $48 \mathrm{hr}$. $\mathrm{T}$ antigen was detected as early as $24 \mathrm{hr}$ after infection, prior to the appearance of $\mathrm{CPE}$, the virus multiplication or the formation of viral antigens. However, $\mathrm{T}$ antigen did not increase so much as did viral antigen even in the later period.

d) It could be concluded that, in the course of virus multiplication in HEK, T antigen was formed prior to the formation of mature infectious virus and that the infection of hamster cells with $\mathrm{Ad} 12$ might be a kind of abortive infection proceeding to the formation of $\mathrm{T}$ antigen and not progressing further to the formation of infectious virus. 


\section{Variety of Antibodies in Sera of TBH}

During the course of the above examinations, it was found that there were at least two kinds of antibody in the sera of $\mathrm{TBH}$ which were used to detect $\mathrm{T}$ antigen. At first, the supernatant of $20 \%$ emulsion of tumor tissue after centrifugation at 3,000 rpm for $20 \mathrm{~min}$ was used as $\mathrm{T}$ antigen. The $\mathrm{T}$ antigen was ultracentrifuged at $30,000 \mathrm{rpm}$ for $60 \mathrm{~min}$. When the supernatant of the ultracentrifugation (abbreviated as SUC) was used in CFT instead of the above $\mathrm{T}$ antigen, some sera of $\mathrm{TBH}$ which were $\mathrm{CF}$ positive against $T$ antigen, did not react with SUC. Other sera of $\mathrm{TBH}$ showed quite the same $\mathrm{CF}$ pattern against SUC as that against $\mathrm{T}$ antigen. Moreover, the former sera were $\mathrm{CF}$ positive againts Ad 12 while the latter were $\mathrm{CF}$ negative against Ad 12. A typical example is shown in Table 7. This fact could be explained by a supposition that the $\mathrm{T}$ antigen might be assorted into two kinds of antigen, TS antigen (tumor soluble antigen, non-precipitable by ultracentrifugation) and TP antigen (tumor precipitable antigen, precitable by ultracentrifugation). TS antigen may be quite disinct from $\mathrm{C}$ antigen, while $\mathrm{TP}$ antigen may have some relationship with $\mathrm{C}$ antigen. The serum of TBH 90 in Table 7 may be anti-TP serum and that of TBH 67 may be anti-TS serum.

Table 7. CFT of sera of tumor bearing hamsters showing different tumor antibodies

\begin{tabular}{|c|c|c|c|c|c|c|c|c|c|c|c|}
\hline \multirow{2}{*}{ Antigen } & & \multicolumn{5}{|c|}{ Serum of TBH 90} & \multicolumn{5}{|c|}{ Serum of TBH 67} \\
\hline & & $1: 4$ & $1: 8$ & $1: 16$ & $1: 32$ & $1: 64$ & $1: 4$ & $1: 8$ & $1: 16$ & $1: 32$ & $1: 64$ \\
\hline \multirow{3}{*}{$\mathrm{T} 3$} & $1: 4$ & 4 & 4 & 3 & 2 & 1 & 4 & 4 & 0 & 0 & 0 \\
\hline & $1: 8$ & 0 & 0 & 0 & 0 & 0 & 4 & 4 & 1 & 0 & 0 \\
\hline & $1: 16$ & 0 & 0 & 0 & 0 & 0 & 4 & 4 & 3 & 0 & 0 \\
\hline \multirow[b]{2}{*}{$\mathrm{T} 3$} & $1: 4$ & 0 & 0 & 0 & 0 & 0 & 4 & 4 & 0 & 0 & 0 \\
\hline & $1: 8$ & 0 & 0 & 0 & 0 & 0 & 4 & 4 & 2 & 0 & 0 \\
\hline & $1: 16$ & 0 & 0 & 0 & 0 & 0 & 4 & 4 & 3 & 0 & 0 \\
\hline \multirow{3}{*}{ Ad 12} & $1: 4$ & 4 & 4 & 3 & 1 & 0 & 0 & 0 & 0 & 0 & 0 \\
\hline & $1: 8$ & 0 & 0 & 0 & 0 & 0 & 0 & 0 & 0 & 0 & 0 \\
\hline & $1: 16$ & 0 & 0 & 0 & 0 & 0 & 0 & 0 & 0 & 0 & 0 \\
\hline
\end{tabular}

TS antigen may be a soluble protein. It could be precipitated in a half saturation of ammonium sulfate and could be purified in a fraction in $\mathrm{NaCl}$ gradient of $\mathrm{DEAE}$ cellulose chromatography. Further purification and characterization of the antigen are now under way. The nature of TP antigen was not clarified. It could be precipitated by ultracentrifugation at $30,000 \mathrm{rpm}$ for $60 \mathrm{~min}$ but the recovery of TP antigen from the pellet was difficult. The analyses of $\mathrm{TP}$ antigen in $\mathrm{CsCl}$ density gradient centrifugation and in $\mathrm{NaCl}$ gradient of $\mathrm{DEAE}$ cellulose chromatography gave no reproducible results. These technical difficulties hampered the analysis of TP antigen.

The origin of anti-TS antibody and anti-TP antibody was not clarified. Both antibodies were found either in sera of TBH, induced by the injection of Ad 12 in suckling hamsters, or in sera of $\mathrm{TBH}$ induced by the transplantation of tumor cells in 
adult hamsters. Therefore, it was necessary to test every serum of $\mathrm{TBH}$ for anti-TP and anti-TS antibodies by CFT. Most of the sera from TBH (over $80 \%$ of the sera so far tested) showed only anti-TS antibody. A small portion of the sera from TBH showed both anti-TS and anti-TP antibodies and a smaller portion of the sera from TBH showed only anti-TP antibody.

\section{Formation of Antigen and Virus in $H E K$}

In the preliminary examinations described above, HEK were infected with a low input multiplicity $\left(1-2 \mathrm{TCID}_{50}\right.$ per cell) and the formation of antigens and virus was followed every $12 \mathrm{hr}$ or every $24 \mathrm{hr}$. A more detailed analysis was carried out by infecting with a high input multiplicity of Ad 12 and examining the formation of antigens and virus with 4 hrs intervals. The results are shown in Table 8 and in Fig. 1 .

After infection TS antigen could be detected at $12 \mathrm{hr}$, TP antigen and $\mathrm{C}$ antigen at $16 \mathrm{hr}$ and $\mathrm{A}$ antigen at $20 \mathrm{hr}$. Viral antigens ( $\mathrm{C}$ antigen and $\mathrm{A}$ antigen) appeared later and increased markedly thereafter, exceeding TS or TP antigens. These findings completely agreed with the results of the preliminary examinations.

Table 8. Development of adenovirus 12 and its antigens in HEK*

\begin{tabular}{|c|c|c|c|c|c|c|c|}
\hline & & \multirow{2}{*}{$\mathrm{CPE}$} & \multirow{2}{*}{ Infectivity } & \multicolumn{4}{|c|}{ Antigen titer with } \\
\hline & & & & $\begin{array}{l}\text { Anti-TS } \\
\text { TBH-88 }\end{array}$ & $\begin{array}{l}\text { Anti-TP } \\
\text { TBH-90 }\end{array}$ & $\begin{array}{c}\text { Anti-C } \\
\text { R.1 }\end{array}$ & $\begin{array}{c}\text { Anti-A } \\
\mathrm{H}-5\end{array}$ \\
\hline & hrs & - & 2.7 & 0 & 0 & 0 & 0 \\
\hline & $\prime \prime$ & - & 2.7 & 0 & 0 & 0 & 0 \\
\hline & $\prime \prime$ & - & 2.5 & $1: 2$ & 0 & 0 & 0 \\
\hline & $\prime \prime$ & - & 1.5 & $1: 4$ & $1: 2$ & $1: 1$ & 0 \\
\hline & $\prime \prime$ & - & 2.5 & $1: 4$ & $1: 2$ & $1: 2$ & $1: 2$ \\
\hline 24 & $\prime \prime$ & + & 4. 3 & $1: 8$ & $1: 8$ & $1: 16$ & $1: 16$ \\
\hline 28 & $\prime \prime$ & ++ & 5.5 & $1: 16$ & $1: 16$ & $1: 64$ & $1: 64$ \\
\hline & $\prime \prime$ & $+t+$ & 6.5 & $1: 32$ & $1: 32$ & $1: 64$ & $1: 64$ \\
\hline 36 & $\prime \prime$ & +++ & 6.5 & $1: 32$ & $1: 32$ & $1: 128$ & $1: 64$ \\
\hline 40 & $\prime \prime$ & +++ & 5.0 & $1: 32$ & $1: 32$ & $1: 128$ & $1: 128$ \\
\hline
\end{tabular}

* Cells were infected with an input multiplicty $50 \mathrm{TCID}_{50}$ per cell and the test materials were prepared from cell suspension with the concentration of $2 \times 10^{6}$ cells $/ \mathrm{ml}$.

A similar examination was carried out from a different angle by the use of antimetabolites, p-fluorophenylalanine (abbreviated as FPA) and 5-Iodo-2'-deoxyuridine (abbreviated as IDU). After infection of HEK with a high input multiplicity of Ad 12, FPA $(300 \mu \mathrm{g} / \mathrm{ml})$ or IDU $(100 \mu \mathrm{g} / \mathrm{ml})$ was added every $4 \mathrm{hr}$. Fourty hrs after infection, the test materials were prepared from the infected cells, and the virus therein was titrated. The results are shown in Table 9.

FPA is regarded as an inhibitor of protein synthesis and IDU as an inhibitor of DNA synthesis. It was, therefore, interpreted that the infectivity must depend on the quantity of coat protein or viral DNA already fromed at the time of the addition of antimetabolites and that the quantity of coat protein or viral DNA at a given time 
must be expressed in terms of $\mathrm{TCID}_{50}$. From this assumption, the relationship between the formation of TS antigen, viral DNA, coat protein and mature virus in HEK is summarized in Fig. 2.

Viral $\mathrm{DN}^{\wedge}$--'nthesis began $16 \mathrm{hr}$ after infection and reached its peak $24 \mathrm{hr}$

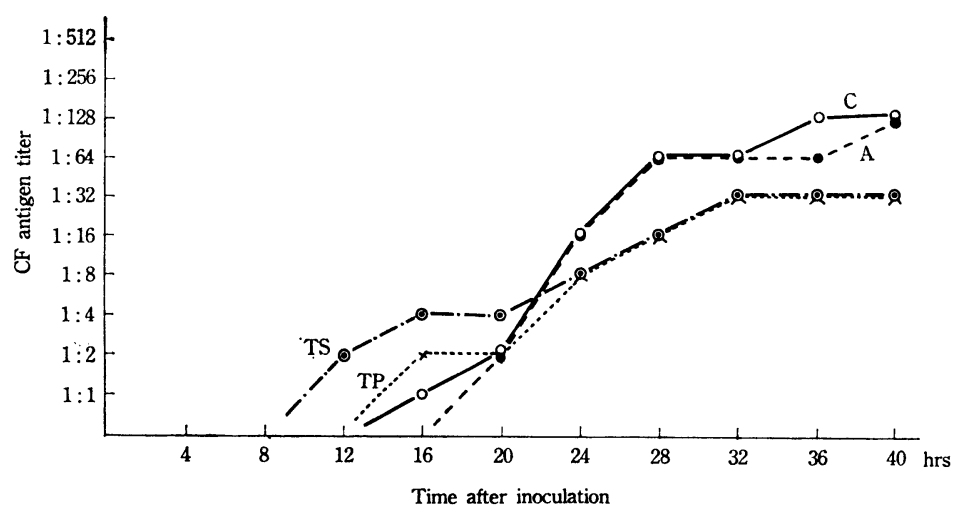

Fig. 1. Development of adenovirus 12 antigens in HEK Input multiplicity $50 \mathrm{TCID}_{\mathrm{s} 0}$ per cell.

Table 9. Influence of IDU and FPA on the development of adenovirus 12 in HEK

\begin{tabular}{ccc}
\hline \multirow{2}{*}{$\begin{array}{c}\text { Addition of the antimetabolite } \\
\text { after infection with Ad 12 }\end{array}$} & \multicolumn{2}{c}{ Antimetabolites added } \\
\cline { 2 - 3 } & IDU** & FPA*** \\
\hline $8 \mathrm{hrs}$ & $3.0^{*}$ & 2.7 \\
$12 \mathrm{hrs}$ & 2.5 & 2.2 \\
$16 \mathrm{hrs}$ & 4.0 & 2.7 \\
$20 \mathrm{hrs}$ & 5.3 & 3.7 \\
$24 \mathrm{hrs}$ & 6.5 & 5.2 \\
$28 \mathrm{hrs}$ & 6.7 & 6.5 \\
$32 \mathrm{hrs}$ & 7.0 & 6.5 \\
$36 \mathrm{hrs}$ & 6.3 & 5.7 \\
\hline
\end{tabular}

* Figures indicate $\operatorname{TCID}_{50} / 0.2 \mathrm{ml}$ of the test materials prepared from cells harvested $40 \mathrm{hrs}$ after infection (Extracts from cell suspensions with the concentration of $2 \times 10^{6}$ cells per ml).

** IDU $(100 \mu \mathrm{g} / \mathrm{ml})$ was added at the indicated time into HEK, infected with an input multiplicity of $17 \mathrm{TCID}_{50}$ per cell.

*** FPA $(300 \mu \mathrm{g} / \mathrm{ml})$ was added at the indicated time into HEK, infected with an input multiplicity of $50 \mathrm{TCID}_{50}$ per cell.

after infection. Coat protein synthesis proceeded in a similar manner as viral DNA synthesis $4 \mathrm{hr}$ later and mature virus synthesis proceeded $8 \mathrm{hr}$ later. TS antigen could be detected $4 \mathrm{hr}$ prior to DNA synthesis. The result showed that TS antigen was formed prior to the synthesis of viral DNA, coat protein and mature virus.

Formation of TS Antigens in Cultured Hamster Cells.

The preliminary examinations described above were carried out by infecting cultured 


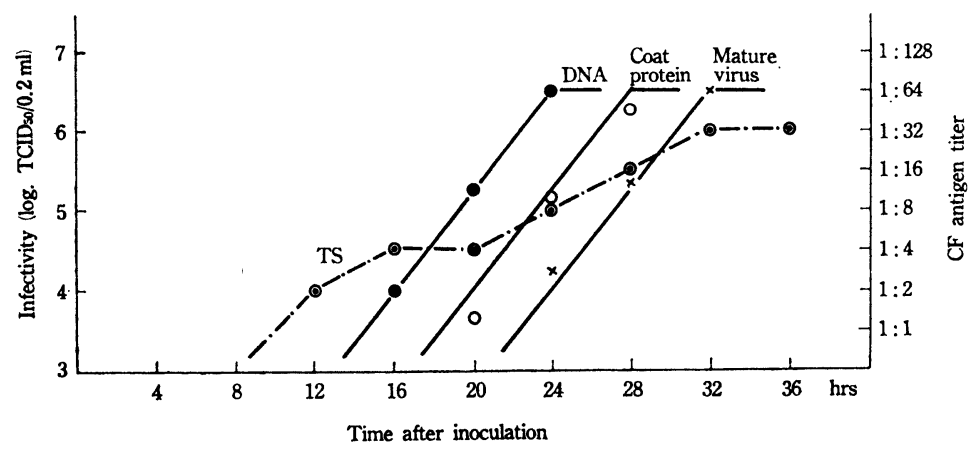

Fig. 2. Development of adenovirus 12 TS antigen, DNA, coat protein and mature virus (summarized scheme).

Table 10. Development of adenovirus 12 antigens in cultured hamster cells from brain, kidney and muscle tissues*

\begin{tabular}{|c|c|c|c|c|c|c|c|c|c|}
\hline \multirow{2}{*}{$\begin{array}{l}\text { Time after } \\
\text { inoculation }\end{array}$} & \multicolumn{3}{|c|}{ Brain } & \multicolumn{3}{|c|}{ Kidney } & \multicolumn{3}{|c|}{ Muscle } \\
\hline & $\begin{array}{l}\text { Anti-TS } \\
\text { TBH } 92\end{array}$ & $\begin{array}{l}\text { Anti-C } \\
\text { GP-2 }\end{array}$ & $\begin{array}{c}\text { Anti-A } \\
\mathrm{H}-5\end{array}$ & $\begin{array}{l}\text { Anti-TS } \\
\text { TBH } 92\end{array}$ & $\begin{array}{l}\text { Anti-C } \\
\text { GP-2 }\end{array}$ & $\begin{array}{c}\text { Anti-A } \\
\mathrm{H}-5\end{array}$ & $\begin{array}{l}\text { Anti TS } \\
\text { TBH } 92\end{array}$ & $\begin{array}{l}\text { Anti-C } \\
\text { GP-2 }\end{array}$ & $\underset{\mathrm{H}-5}{\text { Anti-A }}$ \\
\hline $10 \mathrm{hrs}$ & $2: 1^{* *}$ & 0 & 0 & 0 & 0 & 0 & $1: 1$ & 0 & 0 \\
\hline $12 \mathrm{hrs}$ & $2: 1$ & 0 & 0 & 0 & 0 & 0 & 0 & 0 & 0 \\
\hline $16 \mathrm{hrs}$ & $2: 1$ & 0 & 0 & 0 & 0 & 0 & 0 & 0 & 0 \\
\hline $20 \mathrm{hrs}$ & $2: 1$ & 0 & 0 & 0 & 0 & 0 & $2: 1$ & 0 & 0 \\
\hline $24 \mathrm{hrs}$ & $1: 1$ & 0 & 0 & 0 & 0 & 0 & $2: 1$ & 0 & 0 \\
\hline $28 \mathrm{hrs}$ & $1: 1$ & 0 & 0 & 0 & 0 & 0 & $2: 1$ & 0 & 0 \\
\hline $32 \mathrm{hrs}$ & $1: 1$ & 0 & 0 & 0 & 0 & 0 & $2: 1$ & 0 & 0 \\
\hline $40 \mathrm{hrs}$ & $1: 1$ & 0 & 0 & 0 & 0 & 0 & 0 & 0 & 0 \\
\hline
\end{tabular}

* Cells were infected with an input multiplicity of $20 \mathrm{TCID}_{50}$ per cell and the test materials were prepared from cell suspension with the concentration of $2 \times 10^{6}$ cells $/ \mathrm{ml}$.

** 2 : 1 means CF positive result was obtained when two drops of undiluted antigen was used in stead of a drop of undiluted antigen. In this table, $\mathrm{O}$ means negative CFT even when two drops of undiluted antigen was used.

hamster embryonic cells or cultured hamster kidney cells with a low input multiplicity. Cell lines established from hamsters, such as Hmlu cells* (cell line established from suckling hamster lung by Komiya, Okumura, and Ikegami in our Institute, 1965) and BHK 21 cells*, were also examined. In both cell lines, the quantity of tumor antigen formed was very small and detectable only in the test materials prepared from concentrated cell suspensions such as those with the concentration of $8 \times 10^{6}$ cells $/ \mathrm{ml}$. On the other hand, histopathological studies on tumorigenesis in hamster by Ad 12 suggested that tumor might originate from cells connected with nervous tissue (Ogawa et al., 1966) or with muscle tissue (Chino and Tsuruhara, 1965). Various tissues from

* Both cell lines were given through Dr. H. Okumura, National Institute of Health of Japan, to whom authors express their appreciation. 
suckling hamsters such as the brain, muscle, kidney, liver, lung, heart and so on, were cultured according to the method described above. These cultures were then infected with Ad 12 (input multiplicity $20 \mathrm{TCID}_{50}$ per cell) and the formation of TS antigen, C antigen and $\mathrm{A}$ antigen in the extracts of cell suspensions $\left(2 \times 10^{6}\right.$ cells $\left./ \mathrm{ml}\right)$ was examined. Of the various cultures so far tested, TS antigen was detected only in the cultures from the brain and muscle. Part of the results is shown in Table 10. In the cultures from the brain or muscle, TS antigen was detected as early as $10 \mathrm{hrs}$ after infection. Neither virus multiplication nor CPE (under a low power microscope with unstained cells) was observed.

\section{Discussion}

$\mathrm{T}$ antigen was originally found in hamster tumor induced by $\mathrm{Ad} 12$ and was named as $\mathrm{T}$ (tumor) antigen. Further investigations have shown that $\mathrm{T}$ antigen was also formed in a lytic infection system such as KB cells or HEK (Hoggan et al., 1965, Gilead and Ginsberg, 1965). These findings, as well as the present study in HEK, show that $\mathrm{T}$ antigen is detected not only in tumor cells, but also in cells with a lytic infection. Therefore, some investigators, proposed another name such as ICFA (induced CF antigen, Koprowski, 1965) or neoantigen (Huebner, 1965).

$\mathrm{T}$ antigen was assumed to be separated into two antigens: TS and TP antigens by the pattern of CFT against sera from TBH. A similar phenomenon was reported by Pope and Rowe (1964) who divided sera of TBH into narrow reacting sera (reactive only with tumor extract, not reactive with Ad 12) and broad reacting sera (reactive with both tumor extract and Ad 12). Their report, however, did not describe TBH sera that were not reactive with the SUC and reactive with Ad 12 which were found in the present study. The divison of $\mathrm{T}$ antigen into $\mathrm{TS}$ and TP antigens may, therefore, be rather rational but neither the nature of the antigens nor the conditions for antibody formation have yet been known. There will be no definite conclusion about the composition of $\mathrm{T}$ antigen until these points are clarified.

$\mathrm{T}$ antigen, especially TS antigen, was formed prior to the formation of viral DNA, coat protein, viral antigens and mature virus. This fact suggests that $T$ antigen may be a precursor of viral components or may be an enzyme (or emzymes) necessary for the replication of virus in cells. TP antigen had some relationship with the type specific viral $\mathrm{C}$ antigen, suggesting the possibility that $\mathrm{TP}$ antigen might be a precursor of the viral antigen or might be an incomplete virus. It could possibly be suggested that virus like praticles found in Ad 12 tumors by Smith and Melnick (1964) might be the TP antigen. However, as the nature of TP antigen is entirely unknown no definite estimate can be made. TS antigen is quite distinct from components in virion serologically. According to the analysis of the process of polyoma virus infection in cultured mouse kidney cells (Dulbecco, Hartwell and Vogt, 1965), thymidine kinase activity, dCMP deaminase activity and DNA polymerase activity increased $12 \mathrm{hrs}$ after infection. TS antigen was first detected $12 \mathrm{hrs}$ after infection. The coincidence in time of the increase of enzymatic activity in polyoma virus infection with the appearance of TS antigen in Ad 12 infection may be of significance. At present, however, there is no evdience to support or to deny the possibility that TS antigen may be an enzyme (or enzymes).

When cultured hamster cells were infected with Ad 12, the virus replication 
process proceeded to the formation of $\mathrm{T}$ antigen but further progression had not yet been clarified. No multiplication of infectious virus could be detected nor was CPE observed in unstained cells under a low power microscope. This fact suggests that the infection process in hamster cells may proceed to the phase of $T$ antigen formation; then the process may turn from the normal course of virus replication to a different direction which would finally lead to the transformation of cells.

A preliminary morphological examination of hematoxylin-eosin stained cells after infection with Ad 12 revealed that such a simple explanation might not be applied (Tsuchiya \& Shimojo, 1965). Cell cultures from hamster brain consisted of various kinds of cells as could be expected by the method of cell culture described above. When hamster cells were infected with Ad 12 and hematoxylin-eosin stained preparations were examined periodically after infection, some cells showed intranuclear eosinophilic inclusion bodies $16 \mathrm{hrs}$ after infection. The inclusion bodies appeared as small eosinophilic dots scattered in the nucleus and quite distinct from the inclusion body in HEK which was characterized by the formation of a large central mass in the nucleus. The number of cells with inclusion bodies in the nucleus increased and the inclusion body itself became more apparent as time went on. Thirty-six hrs after infection, karyorrhexis began to be seen in some of the cells with inclusion bodies and the cells degenerated. During this process, there were also many cells which showed no morphological changes and these cells proliferated gradually. These morphlogical changes varied depending on the conditions of the experiment such as the composition of maintenance medium, the multiplicity of infection, etc. Detalied studies are now under way and it can be said that there were at least two kinds (possibly three kinds or more) of cells in cultures from hamster brain. One was apt to form intranuclear inclusion bodies after infection with Ad 12 and might degenerate. The other showed almost no tendency to form inclusion bedies and might survive. The results described in the present study must be obtained from such a mixture of at least two types of reactions after infection with Ad 12. Further investigations along this line, as well as studies of the infection process with fluorescent antibody technique, are necessary to elucidate these problems.

Another point that must be discussed is the quantity of $T$ antigen in tumor cells and in Ad 12 infected cells. The method of preparing standard $\mathrm{T}$ antigen from tumor tissue has been described. It was an extract of $20 \%$ emulsion of tumor tissue and this means, by a rough esmitate, that the antigen was extracted from a cell suspension with the concentration of approximately $10^{8}-10^{9}$ cells $/ \mathrm{ml}$. CF titer of the $\mathrm{T}$ antigen in the extract was usually from $1: 8$ to $1: 32$ Therefore, $10^{7}$ to $10^{8}$ cells may be necessary for the detection of $\mathrm{T}$ antigen with CFT. $\mathrm{T}$ antigen in $\mathrm{H} 4$ cells* (cultured Ad 12 induced hamster tumor cells, established by Yamane, 1965) could also be detected in the extract with the concentration of more than $10^{7}$ cells $/ \mathrm{ml}$. On the other hand, T antigen in cultured hamster cells infected with Ad 12 could be detected in the extract from the cell suspension with the concentration of $2 \times 10^{6}$ cells $/ \mathrm{ml}$. That is, only about one tenth of $\mathrm{T}$ antigen in Ad 12 infected hamster cells was contained in tumor cells. The difference could also be interpreted that the early state of $\mathrm{T}$ antigen in cells infected with Ad 12 may differ from the state of $\mathrm{T}$

* H4 cells was given by Dr. I. Yamane, Tohoku University, to whom authors express their appreciation. 
antigen in tumor cells, in which the viral genetic material may be integrated into the host cell genome. Analyses of these problems using fluorescent antibody technique are also urgently needed.

The authors wish to express their appreciations to Drs. K. Nakano and S. Yamamoto and Mr. G. Kutsukake for the supply of hamsters and to Dr. I. Tagaya for the support of the present study.

\section{REFERENCES}

Ashihara, Y. (1965): Personal communication.

Black, P. H., Rowe, W. P., Tuner, H. C. and Huebnbr, R. J. (1963): Specific complement fixing antigen present in SV40 tumor and transformed cells. Proc. Nat. Acad. Sci., 50, 11481156.

Chino, F. And Tsuruhara, T. (1965): Pathological studies on the oncogenesis of adenovirus type 12 in hamsters. Reported at the 54th General Meeting of Japan. Path. Soc. at Nagasaki City in April.

Dulbecco, R., HaRTwell, L. H. AND VogT, M. (1965): Induction of cellular DNA synthesis by polyoma virus. Proc. Nat. Acad. Sci., 54, 403-410.

EAGLE, H. (1959): Amino acid metabolism in mammalian cell cultures. Science, 130, 432-437.

Fulton, F. AND DUMBELl, K. R. (1949): The serological comparison of strains of influenza virus. J. Gen. Microbiol., 3, 97-111.

Gilead, Z. AND Ginsberg, H. S. (1965): Characterization of a tumor-like antigens in Type 12 and Type 18 adenovirus infected cells. J. Bacteriol., 90, 120-125.

HABEL, K. (1965): Specific complement-fixing antigens in polyoma tumors and transformed cells. Virology, 25, 55-61.

Hoggan, M. D., Rowe, W. P., Black, P. H. and Huebner, R. J. (1965): Production of tumor specific antigens by oncogenic viruses during acute cytolytic infections. Proc. Nat. Acad. Sci., $53,12-19$.

Huebner, R. J., Rowe, W. P. AND LANE, W. T. (1962): Oncogenic effects in hamsters of human adenovirus type 12 and 18. Proc. Nat. Acad. Sci., 48, 2051-2058.

Huebner, R. J., Rowe, W. P., Turner, H. C. And Lane, W. T. (1963): Specific adenovirus complement-fixing antigens in virus free hamster and rat tumors. Proc. Nat. Acad. Soc., 50, 379-389.

Huebner, R. J., Pereira, H. G., Allison, A. C., Hollinshead, A. C. And Turner, H. C. (1964): Production of type-specific $\mathrm{C}$ antigen in virus-free hamster tumor cells induced by adenovirus type 12. Proc. Nat. Acad. Sci., 51, 432-439.

Huebner, R. J., Armstrong, D., Okuyan, M., Sarma, P. S. And Turner, H. C. (1964): Specific complement-fixing viral antigens in hamster and guinea pig tumors induced by the Schmidt-Ruppin strain of avian sarcoma. Proc. Nat. Acad. Sci., 51, 742-750.

Huebner, R. J., CAsey, M. J., Chanock, R. M. AND Schell, K. (1965): Tumor induced in hamsters by a strain of adenovirus type 3 : Sharing of tumor antigens and "neoantigens" with those produced by adenovirus type 7 tumors. Proc. Nat. Acad. Sci., 54, 381-388.

HUEBNER, R. J. (1965): Non-virion neoantigens in cells infected with and transformed by viruses. Presented in May 1965 at the International Conference on Tumor Antigens in Sukhumi, USSR, Sponsored by Union Int. Contre le Cancer, Geneva, Switzerland.

KomiYA, K., OKUMURA, H. AND IKEgAmi, M. (1964): Establishment of a cell line from hamster lung in vitro and characterization of the cells. Annual Bibliography of Tissue Culture Studies in Japan, 56 .

Koprowski, H. (1965): The emperor's new clothes or an inquiry into the present status of tumor 
viruses and virus tumors. Harvey Society Lecture delivered at the New York Academy of Medicine, March 18.

Larson, V. M., Girardi, A. J., Hilleman, M. R. ANd Zwickey, R. E. (1965): Studies on oncogenicity of adenovirus type 7 viruses in hamsters. Proc. Soc. Exptl. Biol. Med,. 118, 15-24.

MCBRIDE, W. D. AND WIENER, A. (1964): In vitro transformation of hamster kidney cells by adenovirus type 12. Proc. Soc. Exptl. Biol. Med., 115, 870-874.

Ogawa, K., Tsutsumi, A., Iwata, K., Fuji, Y., Ohmori, M., Taguchi, K. And Yabe, Y. (1965): Histogenesis of malignant neoplasia induced by adenovirus type 12. GANN, 57, 43-52.

Okuno, T., OYA, A. AND ITO, T. (1961): The identification of Negishi virus. A presumably new member of Russian spring-summer encephalitis virus family isolated in Japan. Japan. J. Med. Sci. Biol., 14, 51-59.

POPE, J. H. AND RowE, W. P. (1964): Immunofluorescent studies of adenovirus 12 tumors and of cells transformed or infected by adenovirus. J. Exptl. Med., 120, 577-588.

Shimojo, H., SAwAmURA, K., WADA, R. AND Yoshikawa, E. (1966). Titration of adenovirus type 12 and type 18 in human embryonic kidney cell cultures. Japan. J. Med. Sci. Biol., 19, 1-8

SMith, K. O. AND MELNICK, J. L. (1964): Adenovirus like particles from cancers induced by adenovirus 12 but free of infective viruses. Science, 145, 1190-1192.

TREnTIN, J. J., YABE, Y. AND TAYLOR, G. (1962): The quest for human cancer viruses. Science, $137,835-841$.

TsuchiYA, Y. AND SHImojo, H. (1965): Unpublished observation.

YAMANE, I. (1965): Mechanisms of carcinogenesis by adenovirus. Kagaku, 35, 660-670(Text in Japanese). 